\title{
Growth Hormone Therapy Improves Growth in Children with Cystic Fibrosis Related Liver Disease
}

\author{
Michael S. Stalvey ${ }^{1,4}$, Daniel M. Torrez ${ }^{2}$, Jennifer Hillan ${ }^{2}$, Regino P. Gonzalez-Peralta ${ }^{3}$, \\ Allah Haafiz ${ }^{3}$ and Arlan L. Rosenbloom ${ }^{1}$ \\ University of Florida, Department of Pediatrics, 'Division of Pediatric Endocrinology, \\ ${ }^{2}$ Division of Pediatric Pulmonology and ${ }^{3}$ Division of Pediatric Gastroenterology, Gainesville, FL and \\ ${ }^{4}$ University of Massachusetts, Department of Pediatrics, Worcester, MA, USA
}

\begin{abstract}
Growth impairment in cystic fibrosis (CF) is worsened by liver disease. Children with $\mathrm{CF}$ have serum levels of insulin-like growth factor-I (IGF-I) that are lower than expected for their normal growth hormone (GH) production. In children with CF-related liver disease (CFLD), response to endogenous $\mathrm{GH}$ is further reduced. We present our experience with two young children with CFLD given recombinant human GH (rhGH). The first patient was a 5 year-old female with CFLD and poor growth who responded well for $1 \frac{1}{2}$ years to rhGH therapy during her initial course and without a significant increase in serum IGF-I, but with a substantial increase in IGF-I concentration when the GH dose was increased. The second patient was a 5 month-old male with advanced liver disease who had transient improved growth and liver function following rhGH. These patients suggest that rhGH is safe and may be effective in children with CFLD.
\end{abstract}

\section{KEY WORDS}

growth hormone, insulin like growth factor-I, cystic fibrosis, liver disease

Reprint address:

Michael S. Stälvey, M.D.

University of Massachusetts Medical School

55 Lake Avenue North

Worcester, MA 01655, USA

e-mail: Michael.Stalvey@umassmed.edu

VOLUME 21, NO. 8, 2008

\section{INTRODUCTION}

In 1938, the mean life expectancy for children with cystic fibrosis (CF) was less than one year, improving to 16 years by the mid-1970s and currently to 36.5 years $^{1,2}$. Resulting from a mutation in the cystic fibrosis transmembrane conductance regulator (CFTR) gene, $\mathrm{CF}$ has an incidence of one in 3,500 live births ${ }^{2}$. Some manifestations of this disease are due to defective CFTR chloride channel function and others are the result of cellular responses to mutant CFTR ${ }^{3-5}$. The interplay of these effects, with poor nutrient absorption and increased metabolic demand of illness, is thought to account for poor growth, although direct effects on growing bone and muscle cannot be discounted. Childhood height and weight for age are independent predictors of lung function and survival ${ }^{6,7}$.

Children with CF have normal growth hormone (GH) secretion, but low serum insulin-like growth factor-I (IGF-I) concentrations ${ }^{8}$. With CF-related liver disease (CFLD) IGF-I levels may be further reduced $^{9}$. GH stimulation of hepatic production of IGF-I is the main source of circulating IGF-I. GH also stimulates hepatic production of the principal binding protein of circulating IGF-I, IGF binding protein-3 (IGFBP-3) and the acid labile subunit (ALS). Some $90 \%$ of IGF-I circulates as a ternary complex with IGFBP-3 and ALS, the latter stabilizing the complex ${ }^{10}$. Administration of recombinant human $\mathrm{GH}$ (rhGH) may improve growth by stimulating IGF-I synthesis in the liver (endocrine) and bone (paracrine), as well as directly stimulating pre-chondrocyte differentiation. Studies suggest that $\mathrm{rhGH}$ treatment improves the growth and clinical course in patients with $\mathrm{CF}^{11,12}$. More specifically, rhGH administration has been associated with increased lean body mass, improved lung 
function, and decreased hospitalizations.

We have treated two children with low IGF-I production and impaired growth, despite substantial caloric intake. Adequacy of endogenous $\mathrm{GH}$ production was determined in both children. We hypothesized that the addition of exogenous $\mathrm{rhGH}$ would stimulate target tissues to improve IGF-I production.

\section{PATIENT REPORTS}

\section{Patient 1}

This child had mild lung disease with infrequent respiratory symptoms, despite being homozygous for the $\Delta F 508$ mutation. She was too young for reliable pulmonary function testing. She had hepatomegaly and markedly elevated serum transaminase levels at 4 months of age. Diagnosed with chronic liver disease, she had been stable on medical therapy for $>2$ years.

At 5 years of age, standard deviation score (SDS) for height was -4 and for weight -3.9 , with poor growth velocity (GV), of $3.5 \mathrm{~cm} / \mathrm{yr}(-4 \mathrm{SDS})$. Her pre-albumin level was low $(12 \mathrm{mg} / \mathrm{dl}$ [normal $\{n l\}: 20-40]$ ) despite gastrostomy tube and oral intake, which was greater than calculated energy needs of $135 \mathrm{kcal} / \mathrm{kg} / \mathrm{day}$. Thyroid, adrenal function and blood glucose levels were normal. After a GH stimulation test using glucagon and clonidine resulted in a peak response of $9.9 \mathrm{ng} / \mathrm{ml}$, we initiated treatment with $\mathrm{rhGH}(0.3 \mathrm{mg} / \mathrm{kg} / \mathrm{wk})$. Her intake improved slightly, from 171 to $194 \mathrm{kcal} /$ $\mathrm{kg}$ /day. She had suboptimal weight gain in the 12 months before $(2.8 \mathrm{~g} / \mathrm{d})$ and after $(3.1 \mathrm{~g} / \mathrm{d}, \mathrm{nl}$ for age 5-8 g/d) starting rhGH. Nonetheless, GV increased to $8.4 \mathrm{~cm} / \mathrm{yr}$ over the first 6 months of rhGH treatment, but serum IGF-I and IGFBP-3 concentrations were unaffected (from 54 to 66 $\mathrm{ng} / \mathrm{ml}$ for IGF-I [nl for age 57-260] and from 1.4 to $2.1 \mathrm{mg} / \mathrm{l}$ for IGFBP-3 [ $\mathrm{nl}$ for age 1.1 to 5.2]). At 9 months into her therapy, her GV continued at 7.5 $\mathrm{cm} / \mathrm{yr}$, but by 12 months her growth slowed to 4 $\mathrm{cm} /$ year. We increased her $\mathrm{rhGH}$ dose to 0.35 $\mathrm{mg} / \mathrm{kg} / \mathrm{wk}$. Her IGF-I level was obtained one month later and had increased to $183 \mathrm{ng} / \mathrm{ml}$, and her AST and ALT normalized (from pretreatment 49 and 45 $\mathrm{U} / 1$ to 35 and $39 \mathrm{U} / \mathrm{l}$ ). In addition, her growth rate improved over the next 7 months to $6.4 \mathrm{~cm} / \mathrm{yr}$.

\section{Patient 2}

This 5 month-old male infant with CFLD and poor growth was born full term with a meconium cyst that was removed along with $15 \mathrm{~cm}$ of bowel in the neonatal period. CFTR genotyping revealed combined heterozygosity for the $\triangle \mathrm{F} 508$ mutation and a nonsense allele (Q493X).

Total parenteral nutrition (TPN) was provided because of prolonged feeding difficulties, with inability to tolerate more than $200 \mathrm{ml} /$ day through the gastrostomy tube without profuse diarrhea. $\mathrm{He}$ subsequently developed severe liver dysfunction, attributed to TPN and CF. Other complications included coagulopathy, ascites, esophageal varices, and gastric erosions. He was listed for liver transplantation; however, weight gain and linear growth were desired to improve outcome with transplantation.

Growth and weight gain were inadequate; length was $62.5 \mathrm{~cm}$ and weight was $6.04 \mathrm{~kg},-1.3$ SDS for length and -1.8 SDS for weight. His birth length was $48.3 \mathrm{~cm}(-0.65$ SDS $)$ and weight $2.75 \mathrm{~kg}(-1.3$ SDS). At 5 months of age, his weight for height was calculated at the $10^{\text {th }}$ percentile. He had jaundice and hepatomegaly. Laboratory studies were remarkable for a total bilirubin of $24.3 \mathrm{mg} / \mathrm{dl}$, with a conjugated fraction of 22.1 . His serum AST and ALT concentrations were 508 and $341 \mathrm{U} / \mathrm{l}$, respectively. PT and PTT were mildly elevated and the pre-albumin level in serum was low. Endocrine evaluation revealed normal thyroid function and $\mathrm{GH}$ production; peak random $\mathrm{GH}$ level was 18.4 ng/ml: Although serum IGF-I was undetectable, IGFBP-3 and ALS levels were normal $(0.7 \mathrm{mg} / 1$ [nl for age $0.7-3.6$ ] and $1.5 \mathrm{mg} / 1$ [ $\mathrm{nl}$ for age $0.7-5.6$ ], respectively), indicating some hepatic response to endogenous $\mathrm{GH}$.

Treatment with rhGH was begun in an effort to improve growth and weight, and accelerate the transition to enteral feeds. His growth immediately improved. Within one month, his length was -0.6 SDS and his weight was -1.3 SDS. There was an improvement in muscle mass and tone and in overall physical activity. In addition, he was transitioned to full enteral feeds within six weeks. No other changes to his care were introduced. His serum transaminase concentrations improved, and 
total and conjugated bilirubin levels decreased to 12.8 and 11.2 , respectively. Coagulation studies and pre-albumin concentrations normalized. IGF-I reached detectable levels. Plans for liver transplantation were postponed.

Improvement did not persist, however. Approximately two months into therapy, weight gain and linear growth rates declined, liver function deteriorated, and he developed persistent coagulopathy. His weight dropped to that before treatment and growth rate decreased below normal for his age. Serum IGF-I concentration also fell below the normal range. Successful transition to enteral feeds was one of the decisive factors to pursue liver transplantation. At 10 months of age, he received his liver transplant and is doing well.

\section{DISCUSSION}

The use of rhGH for growth promotion in individuals with $\mathrm{CF}$ is increasing. There is, however, no safety and efficacy experience with $\mathrm{rhGH}$ treatment in patients with CFLD. Impaired liver function could result in impaired IGF-I production despite normal GH secretion. GH has both direct effects on growing bone differentiation and indirect growth effects through IGF-I produced by the liver or other tissues. One mechanism for the positive responses to $\mathrm{GH}$ seen in children with $\mathrm{CF}$ may be increased direct effects of $\mathrm{GH}$ and increased local production of IGF-I in growing tissues.

Our first patient had an initial dramatic improvement in GV without an increase in circulating IGF-I concentrations, implying a local effect of pharmacological levels of $\mathrm{GH}$ in growing bone. Local GH effects are differentiation and proliferation of chondrocytes with stimulation of paracrine IGF-I synthesis. CFTR expression in osteoblasts indicates a possible mechanism for $\mathrm{CF}$-related growth failure ${ }^{13}$. Extremely low serum IGF-I concentration is seen with normal or near-normal growth in hepatic IGF-I or ALS knockout mice and ALS gene mutation in humans, indicating that the direct effects of $\mathrm{GH}$ in growing tissues and local (paracrine) production of IGF-I may be sufficient for normal growth ${ }^{14-17}$.

We concluded that the low serum IGF-I concentration in patient 1 was the result of CFLD and not directly related to the growth problem. Therefore, IGF-I may not be a good marker for determining candidates for rhGH therapy or for the efficacy of rhGH therapy in CFLD. Subsequently, the increase in circulating IGF-I concentration following the increased dosage also coincided with normalization of the liver transaminase level in serum. It is not possible to distinguish whether this improvement was secondary to the increased dose or improved liver function. In either case, the improved liver function and IGF-I production were, paradoxically, associated with a decline in GV.

Effects of GH on the liver are unclear. Neonatal hepatitis secondary to cholestasis occurs with congenital $\mathrm{GH}$ deficiency ${ }^{18.19}$. Animal models suggest an integral role for $\mathrm{GH}$ in liver regeneration. Pennisi et al. $^{20}$ performed partial $(70 \%)$ hepatectomies in three groups of mice: a) $\mathrm{GH}$ antagonist transgenic mice, in which the action of $\mathrm{GH}$ is blocked, b) liver IGF-I deficient mice that also lacked ALS, and c) control animals with normal $\mathrm{GH}$ and IGF-I levels. GH antagonist mice demonstrated the worst survival rate immediately following surgery $(57 \%)$ compared to the IGF-I and ALS deficient mice $(88 \%)$ and controls $(100 \%)$. Following partial hepatectomy, control mice were able to fully regenerate their liver mass by four days. IGF-I and ALS deficient mice were able to fully regenerate their liver to the original mass by seven days. The $\mathrm{GH}$ antagonist mice that survived were only able to regenerate to $70 \%$ of their original liver mass by four days, and did not regenerate further before sacrifice at seven days. Desbois-Mouthon et al. further describe the complex paracrine interaction of IGF-1 at the rodent liver. Their group utilized a liver IGF-I receptor inactivation mouse to demonstrate a need for upregulation (from the minimal baseline state) of the IGF-I receptor during liver regeneration ${ }^{21}$.

The second patient had a relatively uncommon indication for $\mathrm{rhGH}$ treatment in children. $\mathrm{GH}$ is indicated for treatment of short gut syndrome in adults, although the data on effectiveness are conflicting ${ }^{22.2:}$. There may be a faster transition from TPN to enteral feeds, improving quality of life and reducing health care costs ${ }^{24.2}$. Shulman et al. reported an increase in the mucosal height following $\mathrm{GH}$ therapy in rats that had previously 
undergone $75 \%$ resection of the ileum ${ }^{26}$. Regeneration of rat gut mucosa has been improved with the addition of glutamine to $\mathrm{GH}$ therapy ${ }^{27}$. Although the short gut syndrome indication for $\mathrm{rhGH}$ is not exclusive to adults, experience in children is limited $^{28,29}$.

The infant patient suffered from the various effects of CF with end-stage liver disease, short gut syndrome, and severe growth failure. He had an initial therapeutic response to rhGH, including an increase in weight gain and linear growth, with a successful transition to enteral feedings, and an increase in circulating IGF-I concentration. These findings suggest that early in the course of CFLD, rhGH may be useful. As liver disease progresses and chronic catabolism ensues, however, the ability of the liver and other target tissues to mount an IGF-I response to GH may be lost.

Researchers have examined GH therapy for other catabolic states, primarily in the adult population. The most extensively studied indication for rhGH in adult catabolism is for HIV-associated wasting. In 2004, Moyle et al. reported improvements in lean body mass, physical performance and quality of life in a large (757 patients) randomized, double-blind, placebo-controlled trial of $\mathrm{rhGH}$ in $\mathrm{HIV}^{30}$. Other studies have tried to reverse the catabolic state and overcome resistance to $\mathrm{GH}$. Wallace et al. observed improvements in serum levels of IGF-I, IGFBP-3 and ALS in a randomized, double-blind, placebo-controlled, cross-over study of GH therapy in nine adults with chronic liver disease $^{31}$. In addition, there was an improvement in lean tissue mass of approximately $10 \%$ (measured by total body potassium and bioelectrical impedance). Worsening ascites and edema were noted, however, in four of the individuals. Neither of our patients demonstrated worsening of ascites or edema during rhGH therapy. Nonetheless, this complication should be considered when treating children with hypoproteinemia or ascites.

Both patients illustrate that rhGH therapy may be used in children with CFLD. No adverse events were associated with rhGH therapy. Both children demonstrated a noticeable increase in growth despite their liver disease. Variable biochemical responses were noted following $\mathrm{GH}$ augmentation, suggesting more important direct $\mathrm{GH}$ effects on growing tissue and in stimulating paracrine IGF-I production. These findings suggest the need for additional studies into the biochemical effects of $\mathrm{GH}$ treatment on individuals with $\mathrm{CF}$, as well as in individuals with liver disease.

\section{REFERENCES}

1. Orenstein DM, W'innie GB, Altman H. Cystic fibrosis: a 2002 update. J Pediatr 2002; 140: 156-164.

2. Foundation CF. Patient Registry 2005 Annual Report. Bethesda, MD, 2006.

3. Virella-Lowell I, Herlihy JD, Liu B, Lopez C, Cruz P, Muller C, Baker HV, Flotte TR. Effects of CFTR, interleukin-10, and Pseudomonas aeruginosa on gene expression profiles in a CF bronchial epithelial cell Line. Mol Ther 2004; 10: 562-573.

4. Sagel SD, Accurso FJ. Monitoring inflammation in CF. Cytokines. Clin Rev Allergy Immunol 2002; 23: 41-57.

5. Stalvey MS, Muller C, Schatz DA, Wasserfall $\mathrm{CH}$, Campbell-Thompson ML, Theriaque DW, Flotte TR, Atkinson MA. Cystic fibrosis transmembrane conductance regulator deficiency exacerbates islet cell dysfunction after beta-cell injury. Diabetes 2006; 55: 1939 1945.

6. Konstan MW, Butler SM, Wohl ME, Stoddard M, Matousek R, Wagener JS, Johnson CA, Morgan WJ; Investigators and Coordinators of the Epidemiologic Study of Cystic Fibrosis. Growth and nutritional indexes in early life predict pulmonary function in cystic fibrosis. J Pediatr 2003; 142: 624-630.

7. Beker LT, Russek-Cohen E, Fink RJ. Stature as a prognostic factor in cystic fibrosis survival. J Am Diet Assoc 2001; 101: 438-442.

8. Laursen EM, Lanng $\mathrm{S}$, Rasmussen $\mathrm{MH}$, Koch $\mathrm{C}$, Skakkebaek NE, Muller J. Normal spontaneous and stimulated $\mathrm{GH}$ levels despite decreased IGF-I concentrations in cystic fibrosis patients. Eur $\mathbf{J}$ Endocrinol 1999; 140: 315-321.

9. Wu YL, Ye J, Zhang S, Zhong J, Xi RP. Clinical significance of serum IGF-I, IGF-II and IGFBP-3 in liver cirrhosis. World J Gastroenterol 2004; 10: 2740-2743.

10. Rosenbloom AL. Physiology and disorders of the growth hormone receptor (GHR) and GH-GHR signal transduction. Endocrine 2000; 12: 107-119.

11. Hardin DS, Ferkol T, Ahn C, Dreimane D, Dyson M, Morse M, Prestidge C, Rice J, Seilheimer DK. A retrospective study of growth hormone use in adolescents with cystic fibrosis. Clin Endocrinol (Oxf) 2005; 62: 560-566.

12. Hardin DS. Adams-Huet B. Brown D, Chatfield B, Dyson M, Ferkol T, Howenstine M, Prestidge C, Royce F, Rice J, Seilheimer DK, Steelman J, Shepherds R. Growth hormone treatment improves growth and clinical status in prepubertal children with cystic 
fibrosis: results of a multicenter randomized controlled trial. J Clin Endocrinol Metab 2006; 91: 4925-4929.

13. Shead EF, Haworth CS, Condliffe AM, McKeon DJ, Scott MA, Compston JE. Cystic fibrosis transmembrane conductance regulator (CFTR) is expressed in human bone. Thorax 2007; 62: 650-651.

14. Domene HM, Bengolea SV, Jasper HG, Boisclair YR Acid-labile subunit deficiency: phenotypic similarities and differences between human and mouse. J Endocrinol Invest. 2005; 28 (Suppl): 43-46.

15. Hwa V, Haeusler G, Pratt KL, Little BM, Frisch H, Koller D, Rosenfeld RG. Total absence of functional acid labile subunit, resulting in severe insulin-like growth factor deficiency and moderate growth failure. J Clin Endocrinol Metab 2006; 91 : 1826-1831.

16. Domene HM, Bengolea SV, Martínez AS, Ropelato MG, Pennisi P, Scaglia $P$, Heinrich JJ, Jasper HG. Deficiency of the circulating insulin-like growth factor system associated with inactivation of the acid-labile subunit gene. N Engl J Med 2004; 350: 570-577.

17. Domene HM, Martínez AS, Frystyk J, Bengolea SV, Ropelato MG, Scaglia PA, Chen JW, Heuck C, Wolthers OD, Heinrich JJ, Jasper HG. Normal growth spurt and final height despite low levels of all forms of circulating insulin-like growth factor-I in a patient with acid-labile subunit deficiency. Horm Res 2007; 67: 243-249.

18. Spray CH, McKiernan P, Waldron KE, Shaw N, Kirk J, Kelly DA. Investigation and outcome of neonatal hepatitis in infants with hypopituitarism. Acta Paediatr 2000; 89: 951-954

19. Choo-Kang LR, Sun CC, Counts DR. Cholestasis and hypoglycemia: manifestations of congenital anterior hypopituitarism. J Clin Endocrinol Metab 1996; 81: 2786-2789.

20. Pennisi PA, Kopchick JJ, Thorgeirsson S, LeRoith D, Yakar S. Role of growth hormone $(\mathrm{GH})$ in liver regeneration. Endocrinology 2004; 145: 4748-4755.

21. Desbois-Mouthon C, Wendum D, Cadoret A, Rey C, Leneuve $P$, Blaise A, Housset $C$, Tronche F, Le Bouc $Y$, Holzenberger $M$. Hepatocyte proliferation during liver regeneration is impaired in mice with liverspecific lGF-1R knockout. FASEB J 2006; 20: 773775 .

22. Scolapio JS, Camilleri M, Fleming CR, Oenning LV, Burton DD, Sebo TJ, Batts KP, Kelly DG. Effect of growth hormone, glutamine, and diet on adaptation in short-bowel syndrome: a randomized, controlled study. Gastroenterology 1997; 113: 1074-1081.

23. Szkudlarek J, Jeppesen PB, Mortensen PB. Effect of high dose growth hormone with glutamine and no change in diet on intestinal absorption in short bowel patients: a randomised, double blind, crossover, placebo controlled study. Gut 2000; 47: 199-205.

24. Byrne TA, Wilmore DW, Iyer K, Dibaise J, Clancy K, Robinson MK, Chang P, Gertner JM, Lautz D. Growth hormone, glutamine, and an optimal diet reduces parenteral nutrition in patients with short bowel syndrome: a prospective, randomized, placebo-controlled, doubleblind clinical trial. Ann Surg 2005; 242: 655-661.

25. Migliaccio-Walle K, Caro JJ, Moller J. Economic implications of growth hormone use in patients with short bowel syndrome. Curr Med Res Opin 2006; 22: 2055-2063.

26. Shulman DI, Hu CS, Duckett G, Lavallee-Grey M. Effects of short-term growth hormone therapy in rats undergoing $75 \%$ small intestinal resection. J Pediatr Gastroenterol Nutr 1992; 14: 3-11.

27. Zhou X, Li YX, Li N, Li JS. Glutamine enhances the gut-trophic effect of growth hormone in rat after massive small bowel resection. J Surg Res 200I; 99: 47-52.

28. Ladd AP, Grosfeld JL, Pescovitz OH, Johnson NB. The effect of growth hormone supplementation on late nutritional independence in pediatric patients with short bowel syndrome. J Pediatr Surg 2005; 40: 442-445.

29. Nucci AM, Finegold DN, Yaworski JA, Kowalski L, Barksdale EM Jr. Results of growth trophic therapy in children with short bowel syndrome. J Pediatr Surg 2004; 39: 335-339; discussion 335-339.

30. Moyle GJ, Daar ES, Gertner JM, Kotler DP, Melchior JC, O'Brien F, Svanberg E; Serono 9037 Study Team. Growth hormone improves lean body mass, physical performance, and quality of life in subjects with HIVassociated weight loss or wasting on highly active antiretroviral therapy. J Acquir Immune Defic Syndr $2004 ; 35: 367-375$.

31. Wallace JD, Abbott-Johnson WJ, Crawford DH, Barnard R, Potter JM, Cuneo RC. GH treatment in adults with chronic liver disease: a randomized, doubleblind, placebo-controlled, cross-over study. J Clin Endocrinol Metab 2002; 87: 275 [-2759. 
